\title{
Yabancı Öğrencilerin Turizm Eğitimi Algılarının ve Sorunlarının Belirlenmesi: Giresun Üniversitesi Üzerine Bir Araştırma
}

\section{Dr. Öğr. Üyesi Hakan Akyurt}

Geliș tarihi: 08.11.2019

Kabul tarihi: 09.12.2019

\section{Atuf bilgisi:}

IBAD Sosyal Bilimler Dergisi

Sayı: $6 \quad$ Sayfa: 54-67

Yıl: 2020 Dönem: Kış

This article was checked by Turnitin. Similarity Index 5\%

Bu makalede araştırma ve yayın etiğine uyulmuştur.

${ }^{1}$ Giresun Üniversitesi, Türkiye, hakan.akyurt@giresun.edu.tr, ORCID ID 0000-0002-6522-684X

\footnotetext{
* Sorumlu yazar
}

ÖZ

Dünya'daki eğitim sisteminin iletişim ve ulaşım araçlarının gelişimi ile birlikte çok yönlü bir yapıya kavuşmuştur. Eğitimlerini tamamlamak ve geliştirmek isteyen insanların farklı ülkelere bu amaçla gittikleri görülmektedir. Özellikle son yıllarda bu sayının arttığı ve çok sayıda yabancı öğrencinin birçok farklı ülkede eğitim aldığı belirlenmiştir. Giresun Üniversitesi de çok sayıda yabancı öğrencisi olan ve yabancı ülkelerden eğitim amaçlı olarak öğrenci kabul eden üniversitelerden biridir. Üniversite de turizm alanında eğitim alma amaçlı olarak gelmiş olan öğrencilerin önemli sayıda olduğu bilinmektedir. $\mathrm{Bu}$ yabancı öğrencilerin Giresun Üniversitesinde aldıkları turizm eğitimi hakkındaki görüşleri hem mevcut eğitim hakkında genel bir bilgi sunacak hem de eğitimin durumu ile ilgili tespitlerde bulunulmasını sağlayacaktır. Araştırmanın temel amacı, üniversitelerde verilen turizm eğitiminin yabancı ögrenciler tarafından nasıl algılandığının belirlenmesi ve turizm eğitimi ile ilgili olarak eksikliklerin tespit edilmesidir. Bu şekilde, yabanc1 öğrencileri için turizm eğitimi algılamalarına yönelik olarak iyileștirmeler yapılması da mümkün olacaktır. Araştırmada öğrenci algılamalarının belirlenmesinde kelime ilişkilendirme testi yöntemi kullanılmıştır. Giresun Üniversitesinde turizm eğitimi alan 65 öğrenci bulunduğu belirlenmiş ve tüm öğrencilere kelime ilişkilendirme testine yönelik olarak anket uygulanmıştır. Analizler sonucunda okul, iş ve meslek kavramlarının en çok tekrar edilen kelimeler olduğu belirlenmiştir. Yabancı öğrencilerin turizm eğitimi algılarının bilinç düzeylerinin yeterli düzeyde olduğu tespit edilmiștir.

Anahtar Kelimeler: Turizm, Turizm Eğitimi, Yabancı Öğrenciler, Kelime İlişkilendirme test 


\title{
Determination of Tourism Education Perceptions and Problems of Foreign Students: A Research on Giresun University
}

\author{
Assist. Prof. Dr. Hakan Akyurt
}

First received: 08.11 .2019

Accepted: 09.12.2019

Citation:

IBAD Journal of Social Sciences

Issue: $6 \quad$ Pages: 54-67

Year: $2020 \quad$ Session: Winter

This article was checked by Turnitin. Similarity Index 5\%

${ }^{1}$ Giresun University, Turkey, hakan.akyurt@giresun.edu.tr,

ORCID ID 0000-0002-6522-684X

\begin{abstract}
The education system in the world has reunited a multi-faceted structure with the development of communication and transportation tools. It is seen that people who want to complete and develop their education go to different countries for this purpose. Especially in recent years, this number has increased and many foreign students have been educated in many different countries. Giresun University is one of the universities that has many foreign students and accepts students from abroad for educational purposes. It is known that there are a significant number of students who came to the University for the purpose of education in the field of tourism. The opinions of these foreign students about the tourism education that they received at Giresun University will provide a general information about the current education and will enable the determination of the education status. The main purpose of the research is to determine how tourism education is perceived by foreign students and to identify deficiencies in tourism education. In this way, it will be possible to make improvements to the perception of tourism education for foreign students. In the research, word association test method was used to determine of student perceptions. It was determined that there were 65 students studying tourism at Giresun University and a questionnaire was applied to all students for word association test. As a result of the analysis, it was determined that the concepts of school, work and profession were the most repeated words. It has been determined that the awareness level of foreign students' perception of tourism education is sufficient.
\end{abstract}

* Corresponding Author

Keywords: Tourism, Tourism Education, Foreign Students, Word Association test 


\section{GİRIŞ}

Turizm sektörü gelișen yapısı ve istihdama olan katkısı ile ülkeler açısından önemli bir sektör olarak faaliyet göstermektedir. Özellikle ekonomik kriz dönemlerinde ve işsizlik oranlarının arttığı zamanlarda sektörün ülke ekonomilerine olan katkısı daha iyi anlaşılmaktadır. Sektörün yoğun çalışma koşulları ve mevsimsellik özelliği gibi olumsuz şartlara rağmen, turizm sektörünün istihdama katkısının önemi büyüktür. Rekabet şartlarının ağır olması nedeniyle ürün ve hizmet sunumunda turistik işletmelerin ve de destinasyonlarının farklılıklar yaratması gerekmektedir. Bu nedenle turizm alanında eğitimlerin son yıllarda hem kamu hem de özel eğitim kurumlarında yoğunlaştığ1 görülmektedir. Ulaşım ve iletişim çağının oluşturduğu durumlar sayesinde dünyanın her yerinde verilen eğitimlerin incelenmesi kolaylaşmıştır. Kendi ülkelerinde eğitim almak istemeyen ya da daha nitelikli eğitimler amaçlı olarak insanların farklı ülkelerde eğitim almaya yöneldiği görülmektedir. Sektörün nitelikli personel ihtiyacı nedeniyle turizm eğitimine olan ilgi de doğal olarak artmıştır.

Türkiye, yurt dışından öğrenci konusunda özellikle Türk Cumhuriyetleri, Afrika ve Arap ülkelerinden yoğun talep aldığı ve de ağırlıklı olarak bu ülke vatandaşları olan öğrencilerin üniversitelerimizi tercih ettikleri görülmektedir. Bu kapsamda, Giresun Üniversitesi de yabancı öğrenci kontenjanı bakımından önemli sayıda öğrenciye sahiptir. Genel olarak öğrencilerin milliyetlerini Türk Cumhuriyetleri, Gürcistan, Arap ve Afrika ülkelerinden gelen öğrenciler oluşturmaktadır. Eğitim alınan alanlardan biri de turizm eğitimidir. Giresun üniversitesinde turizm alanında yabancı öğrenciler son beş yıl içinde artmış olup, halen devam eden bir talep söz konusudur. Turizm eğitiminde genel olarak lisans düzeyinde eğitim alan yabancı öğrenciler bulunmaktadır.

$\mathrm{Bu}$ araştırmada ise, turizm alanında eğitim alan öğrencilerin, almakta oldukları turizm eğitimi ile ilgili algılarının ölçülmesi amaçlanmıştır. Turizm eğitimi ile ilgili olarak algılarının tespitinde kelime ilişkilendirme testi yöntemi kullanılmıştır. Kelime ilişkilendirme testinde öğrencilerin turizm eğitimi algısının hangi kelimelerden oluştuğu ve bilinç düzeyleri ölçülmektedir. Kelime ilişkilendirme testi yöntemi ile öğrencilerin turizm eğitimi kavramına ilişkin ilk akıllarına gelen cevap kelimeler elde edilmiş, frekans analizi yapılmıș ve kavram ağı haritası çıkarılarak bulgulara ulaşılmıștır. Çalıșmanın yabancı öğrencilerin turizm eğitimi algısını oluşturan temel yapıyı ve ne kadar bilinçli olarak turizm eğitimini seçtikleri konusunda bilgi vermesi beklenmektedir. Elde edilen sonuçlarla turizm eğitimindeki sorunlara yönelik bilgiler elde edilebilecek ve turizm eğitiminin daha nitelikli olarak sunulmasında katkı sağlanabilecektir.

\section{LITERATÜR TARAMASI}

Eğitim, tüm sektörlerde ihtiyaç duyulan nitelikli personelin yetiştirilmesi ve sürdürülebilir bir sektörel yapının sağlanması nedeniyle zorunlu bir ihtiyaç olarak görülmektedir. İşinde uzman kişilerin artması, sürekli gelişimi ve insanlara daha iyi koşullarda ürün ya da hizmet sunumunun gerçekleştirilmesi anlamı taşımaktadır. $\mathrm{Bu}$ nedenle her iş kolunda nitelikli eğitimlerin verilmesi ve sektörlere kazandırılması zorunluluk olmuştur. Eğitimler ile değişen ve sürekli kendini yenileyen sektörlerin ihtiyaçlarını karşılamak gerekmektedir. Çağın gereklerine göre eğitimlerin yenilemesi ve geliştirilmesi ile sektörel talebi karşılamak mümkün olacaktır. Hem eğitim sistemlerinin hem de eğiticilerin değişen dünya şartlarına uygun olarak yenilenmesi ve geliştirilmesi zorunlu hale gelmiştir.

Bir alanda ya da sektör için yapılan mesleki eğitimler, "insanların bir toplum içinde herhangi bir meslek kolunda çalışabilmeleri ve o meslek kolunda mesleğin içerdiği bilgi ve yeterlilikleri sunmalarında yardımcı olmayı, insanların yeteneklerini arttırarak fiziksel ve zihinsel anlamda mesleğe yatkın bireyler haline dönüşmeyi ve de sosyal ve ekonomik olarak gelişimi sağlama süreci" olarak ifade edilebilir (Aymankuy ve Aymankuy, 2002, s.29). Tezcan (1996), eğitimi toplumlarda insanların bilgi, beceri ve yeteneklerini geliştiren ve yaşamaları için gerekli niteliklere sahip olma süreci olarak tanımlamaktadır. Turizm eğitimleri teknik ve mesleki eğitimler kapsamında değerlendirilir. Teknik ve mesleki eğitimler, bir ülkedeki eğitim sistemi içerisinde bütün sektörleri ele alacak şekilde her türlü teknik ve mesleki eğitimleri kapsamaktadır. Eğitimlerin ve eğitime destek sistemlerinin planlanmasında, araştırılmasında, geliştirilmesinde, organize edilmesinde ve dünya eğitimi ile eş 
zamanlı olarak geliştirilip güncel bir şekilde öğrencilere sunulmasında teknik ve mesleki eğitim sistemlerinin rolü büyüktür (Şahin ve Fındık, 2008, s.65).

Turizm eğitimi, eğitim alanlarından biri olmakla birlikte, turizme yönelik olarak sektörün beklentilerine karşılık verme amaçlı uygulanan bir eğitim türüdür. Turizm alanında eğitim kavramını, "turizm sektörü alanında eğitim vermekte olan kurum ya da kuruluşlarının turizme konu olmuş bilgileri öğrencilere aktarması ve turizm sektörünün arzu ettiği nitelikte öğrenci yetiştirilmesini hedefleyen eğitim sistemi" olarak ifade etmek mümkündür (Mısırlı, 2002, s.41). Turizm eğitimi özellikle son yıllarda birçok eğitim kurumunun açılması ve faaliyete geçmesi ile ülkemizin birçok yerinde öğrenci eğitmeyi amaçlayan bir yapıya sahiptir. Turizm sektörünün yapısı gereği ve rekabet koşullarının giderek daha da ağırlaşması nedeniyle turizm işletmelerinin nitelikli personele olan ihtiyacı gün geçtikçe daha da artmaktadır. Eğitimli ve sektör tecrübesine sahip personelin turizm sektörü içinde önemi ve değeri her geçen gün kendini göstermektedir (Kızılırmak, 2000, s.56). Turizm eğitiminde bir eğitim kurumunun veya ülkenin genelinin bir eğitim sistemini ya da araştırmacılar tarafından sunulan eğitim modeline bağlı kalması mümkün değildir (Dias Daniel vd., 2017, s.67). Ülkelerin özelliklerine göre turizm eğitimleri farkl1lıklar gösterebileceği gibi bir ülke içindeki destinasyonların niteliğine ve turist profiline göre de turizm eğitimleri farklılıklar gösterebilmektedir. Bu nedenle turizm eğitimlerinde bir modele veya tanıma göre turizm eğitimleri düzenlenemez.

Ülkemizde turizm eğitimleri, liseden başlayıp doktora derecesine kadar süren bir yapıda devam etmektedir. Kamu ve özel kurumlar tarafından çeşitli basamaklarda eğitim kurumları ve birimleri ile turizm eğitimleri devam etmektedir. Mesleki açıdan turizm sektörünün beklentilerine cevap verecek şekilde Türkiye'nin her yerinde uygulamalı turizm eğitimleri verilmektedir. Eğitimli turizm ögrencileri, turizm işletmelerine maliyet ve zaman açısından önemli tasarruflar yaptırabilecektir. $\mathrm{Bu}$ durum da rekabet konusunda turizm işletmelerine avantaj sağlayacaktır. Bu nedenden dolayı turizm eğitimlerinin sektörün beklenti ve ihtiyaçlara göre şekillendirilmesi ve günün şartlarına uygun düzenlenmesi gerekmektedir. Eğitimler ile sosyal bilinci yüksek, turizm sektörünün iş koşullarına uyum sağlayabilecek öğrenciler yetiştirilmesi amaçlanmalıdır (Akyurt, 2019, s.762). Turizm eğitimleri hem toplumsal açıdan hem de sosyal açıdan önemli olan eğitimlerdir. Yetiştirilecek öğrencilerin turistler ile karşılaşacak olması ve onların davranışlarına karşı tepkileri önem arz etmektedir. Sosyal anlamda ülke imajının oluşumunda turizm eğitiminin dolaylı olarak etkisi bulunmaktadır. Turistlerle birebir ilişki de bulunmak zorunda kalan turizm sektörü çalışanlarının davranışları ve turistlere karşı tutumları, turistler gözünde ülke insanının imajını şekillendirmektedir. $\mathrm{Bu}$ nedenle, turizm eğitimlerinde sektörün istediği teknik bilgiler ile birlikte, turistlere karşı davranışlar şekillerinin de ögretilmesi gerekmektedir. Bu durum hem ülke turizm imajını dolaylı olarak etkilemekte hem de turistik talebin sürdürülebilirliği açısından tekrar ziyaretleri ya da ülkenin turizm amaçlı tavsiye edilmesinde önemli rol oynamaktadır. Bu nedenle turizm eğitiminin hem sosyal hem de ekonomik olarak ülke gelişimlerinde çok önemli etkilerinin bulunduğu bir gerçektir (Airey vd, 2014, s.145).

Turizm eğitimleri genel olarak birçok farklı amacı içermektedir. Turizmin çok yönlü sektörel yapısına cevap verebilmesi beklenen eğitimlerin hedeflerini kısaca aşağıdaki gibi özetleyebiliriz (Hacıŏ̆lu, Kaşl1, Şahin ve Tetik, 2008, s.15):

- Sektörün tümüne katkıda bulunacak eğitimler vermek,

- Halkın turizme bakış açısını olumlu yönde değiştirmek,

- Sektöre ait uygulamalı ve teorik bilgileri aktarmak,

- Turizm sektörünün nitelikli personel sorununu çözmek,

- Turizmin değerinin ve öneminin anlaşılmasını sağlamak,

- Turizme olan ilginin artmasina yardımcı olmak,

- Turistlere olumlu imaj sunacak personel yetiştirmek,

- Mesleki turizm bilincinin yerleşmesini sağlamak.

Yukarıda belirtilmiş olan hedefler ile birlikte turizm eğitiminin neden verilmesi ve önemli olduğuna ilişkin maddeler aşağıda sıralanmaktadır (Ünlüönen ve Boylu, 2005, s.25) 
- Hizmet kalitesi standartlarını arttırmak; eğitim almış personel turistik işletmelerde ürün ve hizmet sunumunda kalite standartlarını yükseltecektir. Ayrıca turistlerle olan iletişimleri daha iyi olacağı için hizmet kalitesinin seviyesi de artacaktır. Turistlerin istek ve ihtiyaçlarını karşılama da eğitimli olan personelin daha etkin bir rolü olacak ve başarılı bir hizmet sunumu sağlanacaktır.

- Rekabet avantajı; nitelikli ve eğitimli personel ihtiyacı turizm sektörünün önemli bir açı̆̆ olarak görülmektedir. Eğitimli personel turizm işletmelerinde ürün ve hizmet sunumu ile birlikte işletme hedeflerine ulaşmada önemli avantaj sağlayacaktır. Bu durum işletmeler arasındaki farklılığı da belirleyen önemli bir husus olacağı için işletmelerin rekabet avantajı sağlamasında eğitimli personellerin etkisi büyük olacaktır. Ayrıca, olumlu imaj oluşturma da toplumun ikna edilmesinde de eğitimli personel daha etkili olmaktadır.

- Çalışma ortamına uyum, eğitimli personelin kendini ifade etme yeteneği ve işletme hedeflerinde kendine yer edinme çabası daha yoğun olacaktır. İş yerinde yükselme ve terfi isteği eğitimli personelin kişisel hedeflerinden biri olacağı için turizm işletmeleri içinde görev aldıkları ortamlarda uyumları daha iyi olacaktır. Ayrıca, belirlenen görevleri ve işleri yerine getirmede eğitimli personelin daha etkin olacağı düşünülmektedir. Eğitim durumuna göre işletme amaçlarına sahip çıkmak ve geliştirmek daha mümkün olmaktadır.

Turizm eğitiminin temel amac1, turizm sektöründe çalışacak olan personelin temel turizm eğitimleri almas1, öğrencilerin turizm ile ilgili bilinçli bireylere dönüşmesi ve turizm sektörünü yakından tanıyarak yönetim biçimlerini algılamalarını sağlamaktır. Bununla birlikte, öğrencilerin turizm alanında gelişmeleri ile değişimleri yakından takip ederek turizmin sektöründe yararlı bireyler olmalarıdır. Ayrıca, öğrencilerin teknolojiyi ve yeni terminolojileri öğrenmelerini hedeflemektedir. Turizm eğitimleri ile öğrencilerin, turistlere ve çalışma arkadaşlarına karşı olumlu tavırlara sahip insanlar olmaları ve de toplumda sorumluluk sahibi bireyler olarak yer edinmeleri beklenmektedir (Atay ve Yildırım, 2008, s.395).

Turizm sektörünün gelişen yapısı ve diğer sektörlere olan etkisi nedeniyle son yıllarda ekonomik anlamda katkısı büyük olmuştur (Keung, 2000, s.121). Bu ekonomik katk1 da beraberinde turizm eğitimi kurumlarının ve de öğrenci sayısının düzensiz olarak artmasına neden olmuştur. Ancak, turizm eğitiminin lise ve üniversite düzeyinde birçok kurum ve kuruluş tarafından veriliyor olması elbette ki bazı sorunlara da yol açmaktadır. Öğrenci sayısının fazlalı̆̆ı ve sektörün beklentilerine uygun olarak eğitimlerin dizayn edilmemesi gibi önemli sorunlar ile karşılaşılabilmektedir. Baltacı ve arkadaşları (2012) tarafından yapılan araştırmada yükseköğretimde öğrencilerin turizm eğitimi ile memnuniyetlerine ilişkin sonuçlar elde edilmiştir. Bu sonuçlar özetle aşağıdaki gibi ifade edilebilir (Baltac1 vd., 2012, s.23):

- Öğrencilerinin birçoğunun turizm eğitimini bilinçli olarak seçmediği belirlenmiştir,

- Öğrencilerin sektörden beklentileri düşüktür,

- Sektörün yoğun çalışma koşulları öğrencilerde endişe yaratmaktadır,

- Turizmin mevsimsellik özelliği nedeni ile sürekli işe sahip olma konusunda öğrencilerin beklentileri düşüktür,

- Kariyer planlamalarını yapma da öğrencilerin yetersiz olduğu ve motivasyonlarının düşük olduğu görülmektedir,

- Son sınıfta okuyan öğrencilerin gelecek kaygısının daha yüksek olduğu sonucuna ulaşılmıştır.

Turizm eğitim alan öğrencilerin turizm sektörünün gelecekteki çalışanları oldukları gerçeği düşünüldüğünde, turizm sektörüne olan algılamaların sorunsuz olması beklenmektedir. Ancak, turizm sektörünün yapısal özelliği gereği öğrenci algılarında güvensizlik söz konusudur. Ağır çalışma şartları ve sürekli iş algısının olmaması nedeniyle öğrencilerin birçoğunun turizm sektöründen uzaklaştı̆̆ ve farkl1 sektörlere yöneldiği görülmektedir. Bu durum da turizm eğitimi almış olan nitelikli personelin turizm sektöründen farklı sektörlere yönelmesine neden olmaktadır (Sevimli Deniz ve Çelik, 2018, 
s.208). Son yıllarda artan sayısı ile yabancı öğrenciler turizm eğitimi içinde yer almaktadır. Ancak, yaz aylarında stajları dışında turizm işletmelerinde çalışabilmeleri için çalışma izni almak zorunda kaldıkları için birçok öğrenci çalışamamaktadır. Turizm işletmelerinin yasal konulardan dolayı staj dışında çok az öğrenciyi istihdam etmeleri nedeni ile yabancı öğrenciler ya ülkelerine dönmekte ya da farklı sektörlerde çalışmaya zorunlu kalmaktadır. Bu durum yabancı öğrencileri hem turizm sektöründen uzaklaştırmakta hem de Türkiye hakkındaki olumlu algılamalarını olumsuz yönde etkilemektedir. Bununla birlikte genel olarak yabancı öğrencilerin eğitim almak amaçlı geldikleri yerlerde farklı sorunlar yaşadıkları da bilinmektedir.

Yabancı öğrencilerin eğitim konusunda en önemli sorunlarının başında Türkçe dilini öğrenme sorunu gelmektedir. Öğrencilerin genel olarak Türkiye'de herhangi bir işte çalışmak niyetiyle de Türkçeyi öğrendiklerine yönelik olarak çalışmalar bulunmaktadır. Öğrencilerin genel olarak, ya bir yıl bulundukları üniversitelerde Türkçe ders aldığı ya da kendi ülkelerinde gelemeden önce dil öğrenmeye başladığı tespit edilmiştir (Gürbüz ve Güleç, 2016, s.150). Ayrıca, yabancı öğrencilerin eğitimlerinde en önemli sorunlardan birinin de bulundukları şehre ve şehir insanlarına uyumlarının olduğu görülmektedir. Eğitimlerini doğrudan etkileyen bu faktörlerin başında, yurt olmayan bölgelerde ev bulma ve yerel halkla iletişimde sorunlar yaşadıkları belirlenmiştir. Bu durumda da bazı öğrencilerin ya eğitimlerini bırakıp geri döndükleri ya da bu sorunlar yüzünden eğitimlerine ilgi gösteremedikleri ve okul bitirme sürelerinin uzadığı tespit edilmektedir. Yabancı öğrencilerin mali açıdan zorlanması ve çalışma iznine sahip olamamaları nedeniyle hem çalışıp hem okuma imkanının olmaması da diğer önemli eğitim sorunları içerisinde gösterilmektedir (Usta, Sayın ve Güzelipek, 2017, s.576). Yabanc1 öğrencilerin eğitimlerini almaları sırasında etkili olan bazı sorunlar bulunmaktadır. Bu durumlar öğrencilerin eğitim hayatlarını da doğrudan etkilemektedir. Bu sorunlara yönelik olarak çözüm yolları üretmek üniversite yönetimlerinin ve birim yöneticilerinin sorumluluğu olmalıdır. Aksi takdirde y1llar geçtikçe farklı ülkelerde eğitim alma imkanı olan öğrencilerin sayısının azalacağı öngörülebilir. Yabancı öğrencilerin eğitim hayatlarında karşılaşabilecekleri sorunlar genel olarak aşağıdaki şekil1'de ifade edilmektedir (Kıroğlu, Kesten ve Elma, 2010, s. 29):

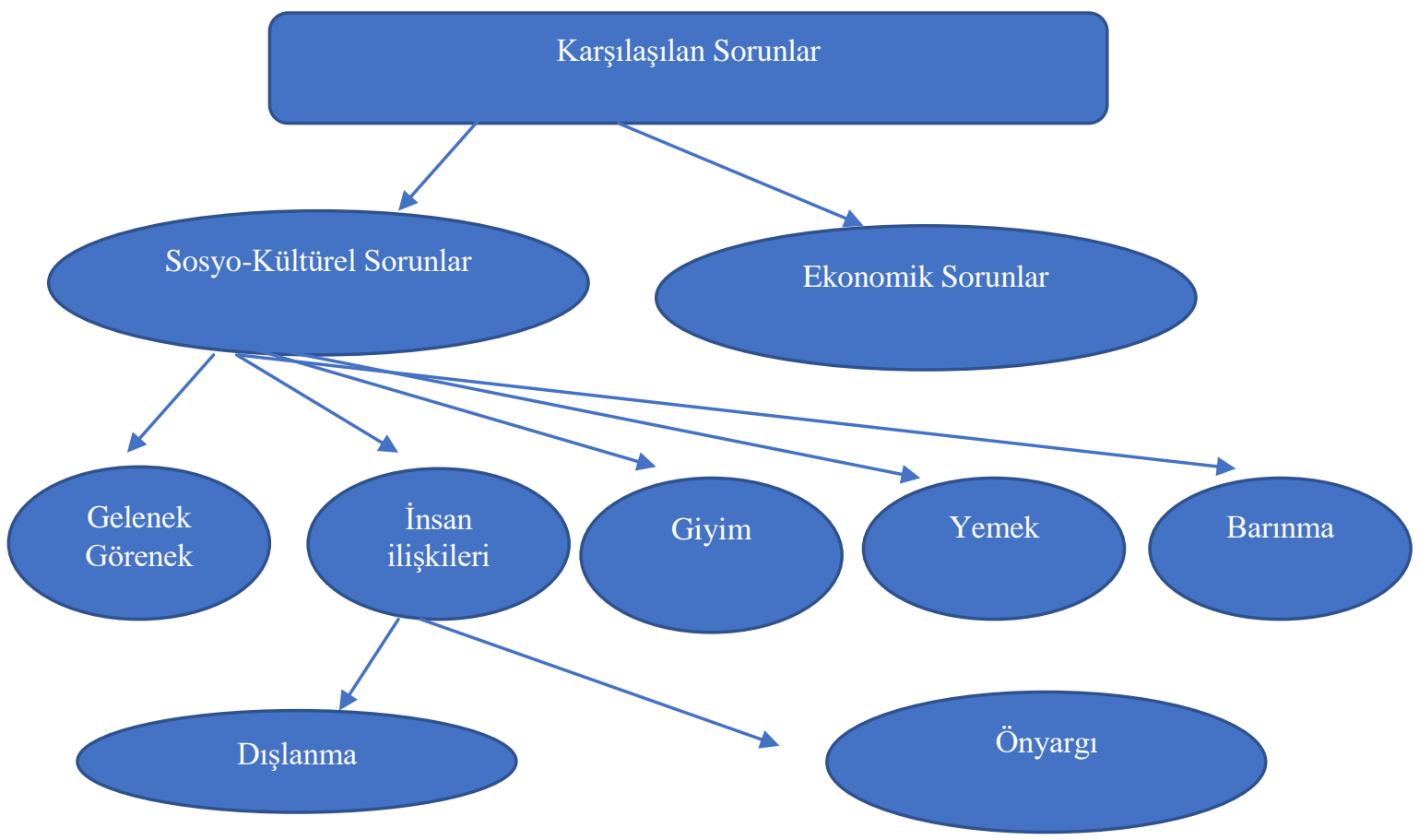

Şekil 1. Yabancı Öğrencilerin Sorunları

Kaynak: Kıroğlu, K., Kesten, A. ve Elma, C. (2010), s.29. 
Yukarıda şekil-1'de belirtilen genel sorunlar nedeni ile yabancı öğrencilerin eğitim hayatı etkilenmektedir. Bu sorunların varlığı aldıkları eğitime karşı önyargılı davranmaları sonucunu ortaya çıkarabilmektedir. Bu nedenle, üniversitede aldıkları eğitime daha objektif bakmaları ve eğitime karşı motivasyonlarını kaybetmemeleri açısından bu sorunların çözümlenmesi gerekmektedir. Aksi takdirde yabancı öğrenciler hem aldıkları eğitimlere hem de yaşadıkları şehir ve insanına karşı olumsuz bir imaj sergileyebilecektir.

\section{ARAŞTIRMANIN ANALIZİ}

\section{Araştırmanın Amacı ve Önemi}

Yabancı öğrencilerin ülkemizde giderek artan sayısı nedeniyle, bu konuda yapılan çalışmaların sayısı artmaya başlamıştır. Günümüz eğitim anlayışında yabancı öğrencilerin önemi, hem ülke imajının olumlu olarak etkilemesi bakımından hem de eğitimleri sırasında ülke insanı ile kaynaşmaları ve kendi ülkeleri içinde eğitim aldıkları ülkenin tanıtımı açısından dikkat edilmesi gereken bir unsurdur. $\mathrm{Bu}$ çalışmada turizm eğitimi alan yabancı öğrencilerin algılamalarının tespit edilmesi ile turizm eğitiminin niteliği hakkında bilgilere ulaşılmış olacaktır. Yabancı öğrencilerin gözünde Türk turizm eğitiminin sorunlarına ve eksikliklerine yönelik veriler elde edilmiş olacaktır. Ayrıca, yabancı öğrencilerin verdikleri diğer cevaplar analiz edilerek, turizm eğitimi hakkında genel çıkarımlar yapılabilecektir. Yabancı öğrencilerden elde edilen bilgiler ile turizm eğitiminin farklı bir açıdan ele alınması, konuyu önemli bir bilgi kaynağı olarak değerlendirilmesini sağlayacaktır. Turizm eğitiminin lisans öğrencileri algısında daha önce Türk öğrencilere yapılan çalışmalar ile kıyaslanarak, aradaki farklılıklar ortaya konulacaktır. Böylece, Türk ve yabancı öğrenci algılarındaki farklılıklara yönelik olarak bilgiler elde edilecektir. Bu bilgiler, turizm eğitiminin sorunlarının belirlenmesi veya olumlu yönlerinin tespitinde önemli verilere ulaşılmasına yardımcı olacaktır.

\section{Araştırmanın Evren ve Örneklemi}

Araştırma Giresun Üniversitesinde turizm eğitimi alan öğrenciler üzerine yapılmaktadır. Aktif olarak Giresun üniversitesinde turizm eğitimi alan lisans öğrenci sayıs1 2015 olup, bunların 65 kişisi yabanc1 öğrencidir. Bu öğrencilerden 57'si erkek, 8'i kız öğrencilerden oluşmaktadır (Giresun Üniversitesi Öğrenci Dairesi Başkanlığı, 2019). Araştırmada uygulanan kelime ilişkilendirme testi anketi 65 yabancı öğrencinin tamamına uygulanmıştır. $\mathrm{Bu}$ duruma göre araştırma evreninin tamamına ulaşıımıştır. Örneklem olarak alınan öğrenci sayısı durumu olmadığından, evrenin tamamı araştırmada temsil edilmektedir.

\section{Araştırmanın Uygulanması}

Araştırmada Giresun üniversitesinde lisans eğitimi alan yabancı öğrencilere kelime ilişkilendirme testi yöntemi ile anket tekniği uygulanmıştır. Anahtar kelime olarak "Turizm eğitimi”" belirlenmiştir. Uygulama öncesinde, öğrencilere kelime ilişkilendirme testi hakkında açıklamalar yapılmış ve kelime ilişkilendirme testinde ankete nasıl cevap verecekleri detaylı olarak anlatılmıştır. Yabancı öğrencilerin turizm eğitimi ile ilgili cevap kelimelerini ankette doldurmaları için 1 dakika süre tanınmıştır. Cevaplarını hızlı bir şekilde doldurmalarının istenme nedeni ise, anahtar kavram olan turizm eğitimi hakkında algılarındaki ilk fikirleri edinmek amaçlıdır. Ayrıca, ankete cevap verirken çevrelerinden ve arkadaşlarından etkilenmelerini önlemek amacı ile süre kısa tutulmaktadır. Yabancı öğrencilerin turizm eğitimi konusunda ilk akıllarına gelen bilgilerin edinilmesi istenmektedir. Arkadaşlarından etkilenmelerini önlemek amaçlıdır. Uygulama aşamasında kelime ilişkilendirme anketinde, "Turizm Eğitimi”" bir sayfa içinde $4 \mathrm{kez}$ alt alta yazılmıştır. Zincirleme olarak cevap verme durumunu önlemek amacı ile alt alta 4 kez yazılmaktadır. Öğrencilerden konu ile ilgili olarak zihinlerindeki daha fazla ilişkili kelime elde edilmesi amaçlı olarak bu şekilde uygulama yapılmaktadır (Polat, 2013, s.104). Anket içinde yabancı öğrencilerin cinsiyet durumları, daha önce turizm sektöründe çalışıp çalışmadıkları, sınıfları ve üniversiteden önce turizm eğitimi alıp almadıklarına ilişkin demografik sorular bulunmaktadır. Kelime ilişkilendirme testi yöntemi ile yabancı öğrencilerin turizm eğitimi algılamalarını ölçmeyi amaçlayan anket örneği aşağıda tablo-1'de verilmektedir (Akyurt, 2019, s.766). 
Tablo 1. Kelime İlişkilendirme Testi Anket Tasarımı

\begin{tabular}{|l|l|}
\hline $\begin{array}{l}\text { Aşağıda verilen kelimeyi gördüğünüzde aklınıza gelen kelimeleri yanlarındaki boşluklara yazınız. } \\
\text { Kelimeleri yazmak için } 60 \text { saniyeniz vardır. }\end{array}$ \\
\hline Turizm Eğitimi & \\
\hline Turizm Eğitimi & \\
\hline Turizm Eğitimi & \\
\hline Turizm Eğitimi & \\
\hline Örnek Cümle & \\
\hline
\end{tabular}

\section{Araştırmanın Yöntemi}

Araştırma içinde iki farklı teknik kullanılmıştır. Birinci kısımda demografik bilgilerin analizinde SPSS 22 programı ile analiz yapılmış, ikinci kısımda ise kelime ilişkilendirme testi ile yabancı öğrencilerin turizm eğitimi algılamalarını belirlemek amaçlı frekans analizi ve kavram ağı haritası çıkarılmıştır. Kelime ilişkilendirme testi yöntemi, anahtar kavram ya da kavramlar ile öğrenci algılarındaki bağların ortaya konulmasında yardımcı olan bir yöntemdir. Anahtar kavram ile cevap kelimeler arasındaki ilişkilerin analiz edilmesinde en çok kullanılan yöntemlerden biri olarak kabul edilmektedir (Ekici ve Kurt, 2014, s.274). Kelime ilişkilendirme testi yöntemi ile öğrenci algılarındaki bilgiler ve bu bilgiler ile ilişkili kavramlar aralarındaki ilişkiler anlam durumuna ve yeterliliklerine göre belirlenmeye çalışılmaktadır. Kelime ilişkilendirme testi yöntemi bu ortaya konulan ilişkileri ölçmek ve değerlendirmeler yapmak amaçlı olarak kullanılan bir yöntem olarak kabul edilmektedir (Işıklı, vd., 2011, s.52). Anketlerden elde edilen cevap kelimeler ile frekans tabloları oluşturulmakta, tüm cevap kelimelerin sayımı ile anahtar kavram arasındaki ilişkiler incelenmekte ve kavram ağları ile önemli görülen ilişkiler ifade edilmektedir. Bu yöntem ile öğrencilerin zihinlerindeki anahtar kavrama ilişkin algıları ortaya konmaktadır (Ay, 2011, s.1571). Kelime ilişkilendirme testi yöntemi ile insanların algılarında kavram ile ilgili olan uzun süreli hafızalarındaki bilgiler arasındaki ilişkiler ortaya konmaya çalışılmaktadır. Anahtar kavram ile cevaplanan kelimeler arasındaki ilişkilerin yeterlilik derecesi ve ilişkiler incelenmektedir (Bahar ve Özatl1, 2003, s.76). Bu yöntem ile sadece anahtar kavrama ilişkin durum analiz edilmemekte, insanların genel olarak konu hakkındaki düşünceleri de elde edilmektedir. Amaçlardan biri de insanların düşüncelerinde hangi kelimelerin canlandığının genel bir tespitinin yapılmasıdır (Çardak, 2009, s.140).

\section{Araştırma Bulguları}

Araştırmada öncelikli olarak SPSS programı ile öğrencilerin demografik bilgilerine yönelik olarak analiz yapılmıştır. $\mathrm{Bu}$ analiz sonuçlarına göre elde edilen bulgular Tablo-2'de gösterilmektedir.

Tablo 2. Demografik Veriler Tablosu

\begin{tabular}{|c|c|c|c|}
\hline Değişken & Seçenek & $\mathbf{n}$ & $f(\%)$ \\
\hline \multirow{2}{*}{ Cinsiyet } & Kadın & 8 & 12,30769 \\
\hline & Erkek & 57 & 87,69231 \\
\hline \multirow{3}{*}{ Sinif } & 2. Sinif & 30 & 46,15384615 \\
\hline & 3. Sinif & 23 & 35,38461538 \\
\hline & 4. Sinif & 12 & 18,46153846 \\
\hline \multirow{3}{*}{$\begin{array}{l}\text { Turizm Sektöründe } \\
\text { Çalışınız mı? }\end{array}$} & Evet & 38 & 58,46153846 \\
\hline & Hayır & 24 & 36,92307692 \\
\hline & Yanitsiz & 3 & 4,61538461 \\
\hline \multirow{3}{*}{$\begin{array}{l}\text { Turizm Eğitimi Aldınız } \\
\text { mı? }\end{array}$} & Evet & 13 & 20 \\
\hline & Hayır & 48 & 73,84615385 \\
\hline & Yanitsiz & 4 & 6,153846154 \\
\hline \multirow{4}{*}{$\begin{array}{l}\text { Türkiye'deki Turizm } \\
\text { Eğitiminden Memnun } \\
\text { Musunuz? }\end{array}$} & Hiç Değilim & 1 & 1,53846153 \\
\hline & Değilim & 9 & 13,84615385 \\
\hline & Fikrim yok & 16 & 24,61538462 \\
\hline & Memnunum & 25 & 38,46153846 \\
\hline
\end{tabular}




\begin{tabular}{lccc}
\hline & Çok memnunum & 11 & 16,92307692 \\
& Yanitsız & 3 & 4,61538461 \\
\hline TOPLAM & & 65 Kİ̧̦̇̇ & $\% 100$ \\
\hline
\end{tabular}

Demografik bilgiler tablosunda da görüleceği üzere, yabancı öğrencilerde erkek öğrencilerin çok daha ağırlıklı (57 öğrenci) olduğu görülmektedir. Öğrencilerin yarısından fazlasının (38 kişi) turizm sektörü tecrübesi vardır. Yabanc1 öğrencilerin önemli bir kısmının $(\% 73,8)$ daha önce turizm eğitimi almadıkları belirlenmiştir. Turizm eğitimi konusunda memnuniyetlerine yönelik soruya cevaplarında yabancı öğrencilerin \%38'i memnun olduklarını belirtmiş, çok memnun olduğunu belirten yabancı öğrenci oranı ise \%16,9 olarak belirlenmiştir. Fikrinin olmadığını ifade eden ve dikkat çeken bir sonuç olarak \%24 oranında 11 öğrenci turizm eğitimi konusunda herhangi bir görüş belirtmemiştir. Aldıkları turizm eğitiminden memnun olmayan 9 öğrenci $(\% 13,8)$ ve hiç memnun olmayan 1 öğrenci $(\% 1,5)$ bulunduğu görülmektedir.

Demografik bulguların belirlenmesi aşamasından sonra kelime ilişkilendirme testinin frekans tablosunu belirlemeye yönelik olarak, "turizm eğitimi" temel kavramına verdikleri cevap kelimeler hesaplanmıştır. Öğrencilerin cevap kelimelerinden oluşan frekans dağılımları Tablo-3'te verilmektedir.

Tablo 3. Kelime İlişkilendirme Testi Frekans Tablosu

\section{Kelime İlişkilendirme Testi Aracılığıyla Yabancı Öğrencilerin Turizm Eğitimi Kavramıyla ilişki Kelimeler}

\begin{tabular}{llll}
\hline acenteler & diller & güneş (5) & keşfetmek \\
\hline Antalya (2) & dinlenme & hava & kış turizmi \\
\hline antika & dinlenmek & hayat (2) & kitap \\
\hline araştırma & doğa (4) & hizmet (4) & kolay (2) \\
\hline bankamatik & düşük & hoca & kötü (6) \\
\hline bar (3) & düzen & huzur (2) & kum (5) \\
\hline berbat & eğitim (5) & içecek & lise \\
\hline Bulancak & ekonomi (4) & iletişim becerisi & macera \\
\hline coğrafya (3) & eleman & iş (7) & manzara \\
\hline çalışma & endüstri & işletmecilik & matematik \\
\hline çalışmak & evler pahalı & iyi (2) & meslek (8) \\
\hline çocuk & fiyat (3) & iyi hizmet & muhasebe \\
\hline dă̆ & garson (3) & Karadeniz & mutfak (2) \\
\hline deniz (8) & genç & karakter & müşteri (4) \\
\hline deniz, kum, güneş (2) & Giresun & kat hizmetleri & okul (9) \\
\hline ders & güler yüzlü personel & & \\
\hline
\end{tabular}

Turizm Eğitimi Kavramıyla İlişkilendirilen Toplam Kelime Sayısı: 62

Elde Edilen Kelimelerin Tekrar Edilme Sayıs1:261

Boş bırakılan Kelime Sayısı: 64

Kelime ilişkilendirme testinde öğrencilerin verdikleri cevaplar için turizm eğitimi anahtar kavramına ilişkin 5 adet cevap yazmaları istenmiştir. Frekans analizi sonucunda öğrencilerin 64 ifadeyi boş bıraktıkları, turizm eğitimi konusunda tekrar edilen 261 kelime olduğu ve turizm eğitimi ile doğrudan bağlantılı 62 kelimenin olduğu belirlenmiş̧tir. Cevaplanan kelimelere göre en çok tekrar edilen kelimelerin okul (9), deniz (8), meslek (8), İş (7), kötü (6), kum (5), güneş (5) ve eğitim (5) olduğu görülmektedir. Frekans dağılımlarının bulunmasından sonra öğrencilerin verdikleri cevaplara göre kelime ilişkilendirme testi yöntemi ile kavram ağı haritası çizilmiştir. Cevap kelimeler ile anahtar kavram arasında ortaya konulan ilişkilere yönelik olarak çizilen kavram ağı haritası Şekil-2'de belirtilmektedir. 


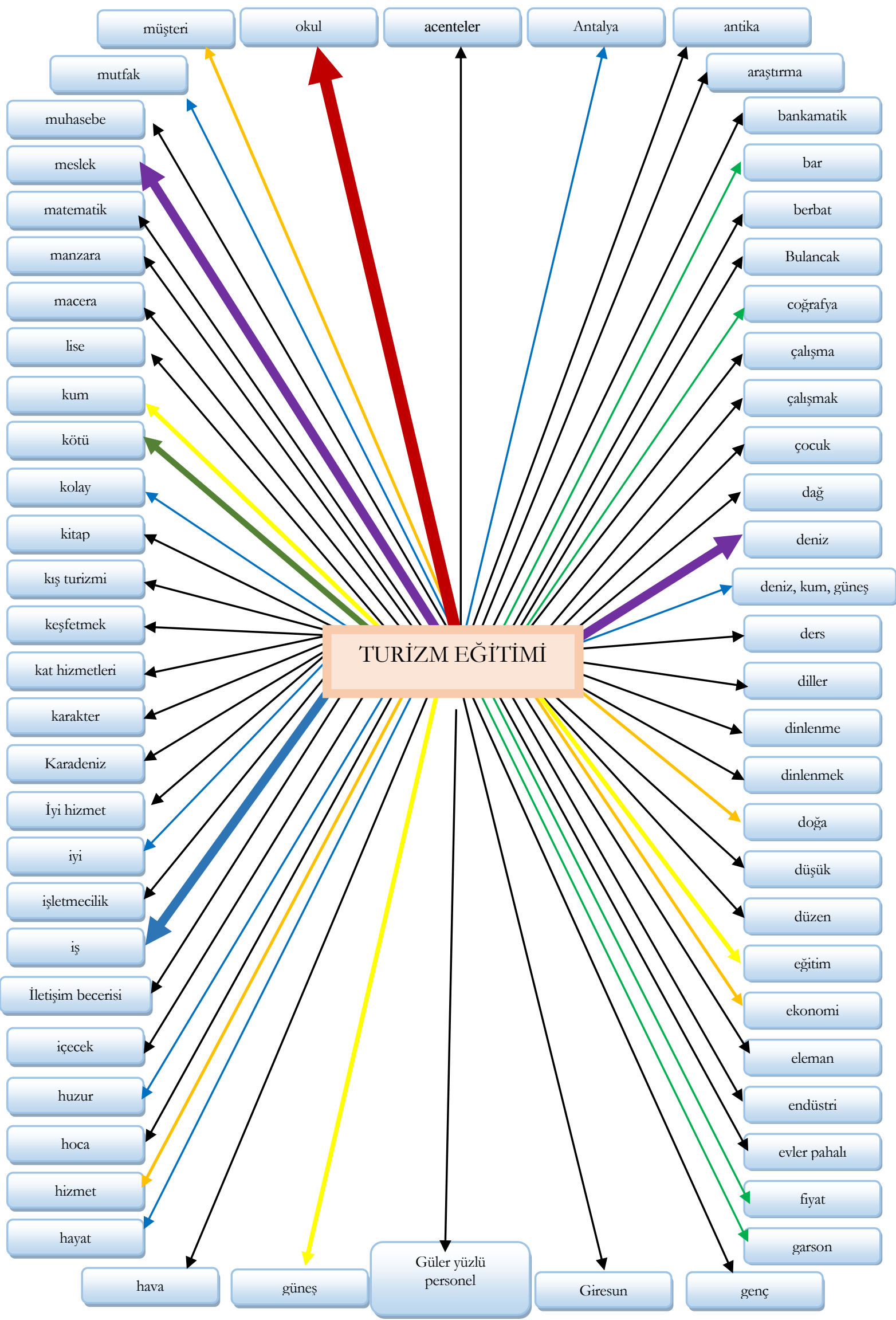

Şekil 2. Turizm Eğitimi Kavram A $\breve{g}$ l Haritası 
Kavram ağı haritasında öğrencilerin anahtar kavram olan "turizm eğitimi" kavramına zihinlerinde ilk düşündükleri kelimeleri yazmaları sonucu ortaya çıkan kelimeler çizilmektedir. Kavram ağı haritaları, anahtar kavram ya da kavramlar ile cevaplanan kelimeler arasındaki ilişkilerin grafiksel olarak gösterilmesini ifade etmektedir. Öğrencilerin anahtar kavramları nasıl algıladıkları ve zihinlerinde nasıl sentezlediklerini anlamlandırmaya yarayan bir grafiktir. Öğrencilerin anahtar kavrama ilişkin eğitim almış olmaları, zihinlerindeki olgunun daha iyi ifade etmeleri açısından önemlidir (Kaya, 2003, s.71). Fen bilimleri eğitimi alanında sıkça kullanılan bu yöntem, daha sonra sosyal bilimler alanında da kullanılmaya başlanmıştır. Öğrencilerin konu hakkında bilgilerinin ölçülmesi amacı ile algılamalarındaki bilişsel durumun tespitinde önemli verilere ulaşılmasında faydalı bir yöntemdir (K1lınç, 2007, s.47). Kelime ilişkilendirme testi yöntemi genel olarak eğitim bilimleri alanında kullanılmakla birlikte, özellikle son yıllarda turizm gibi sosyal bilimler alanlarında da algılamaların analizinde kullanılmaya başlanmıştır.

Turizm eğitimi anahtar kavramına yabancı öğrencilerin verdikleri cevaplar sonucu oluşan kavram ağ haritasında "okul" kelimesi en çok tekrarlanan kelime olarak ortaya çıkmaktadır. Öğrencilerin turizm eğitimi ile okul kelimesini özdeştirdikleri ve zihinlerindeki algılamalarında eğitim ile okul ilişkisini kurdukları görülmektedir. Bununla birlikte, meslek ve iş kelimeleri de sık tekrarlanan kelimelerdir. $\mathrm{Bu}$ kelimelerin tekrar sıklı̆gı, yabancı öğrencilerin turizm eğitimi kavramı hakkında bilişsel yapılarında doğrudan ilişkili bir mantık kurduklarını göstermektedir.

\section{SONUÇ VE ÖNERILER}

Çalışma, ülkemize gelen yabancı öğrencilerin hem turizm eğitimi hem de genel sorunlarına 1 șık tutmak ve çözüm önerilerinde bulunmak amacı ile yapılmıştır. Yabancı öğrenci sayısının gün geçtikçe arttığı ülkemizde, turizm eğitimi alanı da yabancı öğrenciler tarafından tercih edilen bir alandır. Dünya'daki ekonomik durum nedeni ile turizm sektörü son y1llarda artan önemi ile dikkat çeken bir sektör haline gelmiştir. Bu nedenle turizm eğitimi almak isteyen ve kendini bu alanda yetiştirmek isteyen insanlar turizm eğitimi almak için farklı ülkelere de gitmektedir. Bu kapsamda, Türkiye'ye turizm eğitimi almak amaçlı birçok öğrenci gelmektedir. Bu öğrencilerin turizm eğitimi algıları ve ülkemizde karşılaştıkları sorunların neler olduğunun belirlenmesi ve çözüm yollarının aranması ülke imajı ve de turizm eğitimi açısından önem arz etmektedir. Yabancı öğrencilerin Türk öğrencilerden farklı kültürel yapı ve sosyal çevreden geldiği düşünüldüğünde, bu öğrencilerin turizm eğitimine uyum sağlamaları ve ülkemizde karşılaştıkları sorunların tespiti gerekmektedir.

Yabancı öğrencilerinden her birinin ülkemiz açısından turizm elçisi olarak kendi ülkelerinde Türkiye'yi anlatacak olmaları ve Türkiye'deki eğitim kalitesi hakkındaki fikirlerini diğer vatandaşlarına aktaracak olmaları bakımından, yabancı öğrencilerin durumu üzerinde önemle durulması gereken bir konudur. Bu çalışmada, Giresun Üniversitesinde turizm eğitimi alan yabancı ögrencilerin tümüne turizm eğitimi konusunda kelime ilişkilendirme testine yönelik olarak anket yapılmıştır. $\mathrm{Bu}$ anket sonucunda, öğrencilerin turizm eğitimine ilişkin algılarının neler olduğu tespit edilmiştir. Bu sonuçlara göre okul, meslek ve iş gibi doğrudan turizm eğitimi ile ilgili algıların yüksek olduğu ortaya çıkmaktadır. Demografik sorularda elde edilen bilgilere göre öğrencilerin önemli bir kısmının verilen turizm eğitiminden memnun olduğu (\%55), bir kısmının memnun olmadığı (\%15) ve önemli bir kısım öğrencinin de yorum yapmadığı $(\% 24)$ ortaya çıkmaktadır.

Giresun Üniversitesinde turizm eğitim alan yabancı öğrencilerin genel sorunlarını; Bulancak, evler pahalı ve bankamatik gibi cevaplar ile ifade etmektedirler. Genel olarak yerel halktan şikayetleri, okul dışı sosyal hayata ilişkin yetersizlikler ve genel fiyatların pahalı olduğuna dair düşüncelerini paylaştıkları belirlenmiştir. Yabancı öğrencilerin ankette fikirlerinin sorulduğu alana yazdıkları cevaplarda, staj bulma, çevre, yaşadıkları yer, Türk öğrenciler ve hocaları konusunda sorun yaşadıklarını belirtmektedirler. Özellikle stajyer alımlarında staj süresi sonrasında çalışacak öğrencilerin staja alındığını ve yabancı öğrencilerin çalışma izni sorunu yüzünden staj yeri bulurken zorlandığını anlatan ifadeler bulunmaktadır. Yabancı öğrencilerin yeni ortamlarına alışmada zorlandıkları, ev bulma ve alışveriş imkanları konusunda yerel halk ile sorunlar yaşadıklarına dair bilgilere ulaşılmıştır. Yerel halkın olumsuz tutum ve davranışlarından rahatsız olduklarını, bu önyargının derslerini de olumsuz etkilediğini ifade etmektedirler. Türkçe anlama ve yazma konusunda 
zorlandıklarını, daha önce Türkçe kursu almış olsalar bile yeterli olmadığını ifade etmektedirler. Bununla birlikte, hocaların yabancı öğrencilerin anlama zorluğuna göre ders işlemediklerini ve bu nedenle başarısız olduklarını belirtmektedirler. Turizm eğitimi konusunda literatür bilgisi açısından sorun olmadığını ancak uygulama alanlarının dar olduğunu belirten ifadeler bulunmaktadır. Uygulama derslerinin ağırlıklı olarak yapıldığı ders sistemi istediklerini ifade etmektedirler.

Yabancı öğrencilerin hem ülkemizin imajı hem de turizm eğitimi konusunda algılamalarının önemli olduğu düşünüldüğünde, aşağıdaki öneriler ortaya çıkmaktadır.

- Yabancı öğrencilerin sadece eğitimleri ile değil, günlük yaşamlarına ilişkin sorunlara yönelik olarak üniversitelerde birimler oluşturmak,

- Yerel halk ile yabancı öğrencilerin kaynaştırılması için özel tanıtım ve kaynaştırma günleri düzenlemek,

- Yabancı öğrencilerin sadece para getiren kişiler olarak görülmemesi ve ülkemiz için birer turizm elçisi olacaklarını düşünerek, yabancı öğrencilere karşı davranış biçimlerini geliştirmek,

- Sosyal aktiviteler ve imkanlar arttırılarak, yabancı öğrenciler ile Türk öğrencilerin daha çabuk kaynaşması sağlamak,

- Yabancı öğrencilerin staj yeri bulma konusunda zorlanabilecekleri düşünülerek, üniversite hocaları tarafinda staj yeri bulma konusunda destek vermek,

- Turizm eğitimi hakkında daha önce turizm alanında çalışmamış öğrenciler dikkate alınarak, okula başladıkları zamanda oryantasyon eğitimleri vermek,

- Hocaların yabancı öğrencilerin anlama ve yazma kapasitelerini dikkate alarak, yabancı ve Türk öğrencilerin ortak bir şekilde algılayabileceği ders sistemi üretmeleri gerekmektedir,

- Yabancı öğrencilerin turizm eğitimi algısının olumlu olarak değiştirilmesi amacıyla, sektörel geziler ve toplantılar düzenlenmek,

- Turizm eğitimlerinin nitelik açısından geliştirilmesinde yabancı öğrencilerin sorunlarını da dikkate alarak yenilikler yapmak,

- Uygulamalı turizm eğitimleri arttırılarak, turizm sektörü konusunda yabancı öğrencilerin bakış açılarını olumlu yönde değiştirmek,

- Yabanci öğrencilerin kendi ülkelerindeki turizm eğitimleri hakkında bilgiler toplayarak, turizm eğitimlerinin hem yabancı hem de Türk öğrenciler açısından kalitesinin nasıl artırılacağına yönelik olarak çalışmalar yapmak.

- Yabancı öğrencilerin Türkçe öğrenmelerini kolaylaştıracak yöntemlerin uygulanması ve daha kısa sürede Türkçe diline uyum sağlamalarını sağlayacak çalışmalar yapılması uygun olacaktır.

Ülkemizdeki yabancı öğrencilerin turizm eğitimi ve eğitim aldıkları yerlerdeki günlük sorunlarının bir arada değerlendirilmesi, eğitimlerin daha etkili olması bakımından önem arz etmektedir. Yabancı öğrencilerin uyum sorununun giderilmesi ve aldıkları eğitimlere alışmalarını hızlandırmak için üniversite hocalarının ve de yönetimlerinin bu konu hakkında özen göstermesi gerekmektedir. Ülkemizin imajının ve eğitimlerin niteliğinin yurt dışında olumlu yönde tanıtılması, yabancı ögrencilere karşı sergilenen tutum ve de davranışlarla doğru orantılı bir şekilde ilerlemektedir. $\mathrm{Bu}$ nedenle, yabancı öğrencilerin ülkemize ilk geldikleri zamandan ülkelerine dönecekleri zamana kadar her türlü desteğin sağlanması gerekmektedir.

\section{KAYNAKLAR}

Airey, D., Tribe, J., Benckendorff, P. and Xiao, H. (2014). The managerial gaze: The long tail of tourism education and research. Journal of Travel Research, 54(2), 139-151.

Akyurt, H. (2019). Turizm lisans öğrencilerinin kelime ilişkilendirme testi yöntemi ile turizm 
eğitimi algılamalarının ölçülmesi: Giresun Üniversitesi örneği. Türk Turizm Araştırmaları Dergisi, 3(3), 759-774.

Atay, L. ve Yıldırım, H. (2008). Lisans düzeyinde turizm eğitimi alan öğrencilerin profili ve tercihlerine yönelik bir araştırma. IV. Lisansüstü Turizm Öğrencileri Araştırma Kongresi, s.394-408.

Ay, M. (2011). Conceptual frameworks of university students regarding accounting. African Journal of Business Management, 5(5), 1570-1577.

Aymankuy, Y. ve Aymankuy, Ş. (2002). Önlisans ve lisans düzeyindeki turizm eğitimi veren yükseköğretim kurumlarının bulundukları yerlerin analizi ve turizm eğitimi için öneri bir model. Turizm Eğitimi Konferansi/Workshop, 11-13 Aralık, s: 29-42, Ankara.

Bahar, M. ve Özatlı, S. (2003). Kelime iletişim testi yöntemi ile lise 1. Sınıf öğrencilerinin canlıların temel bileşenleri konusundaki bilişsel yapılarının araştııılması. Balıkesir Üniversitesi Fen Bilimleri Enstitüsü Dergisi, 5(2), 75-85.

Baltac1, F., Üngören, E., Avsallı, H. ve Demirel, O.N. (2012). Turizm eğitimi alan öğrencilerin eğitim memnuniyetlerinin ve geleceğe yönelik bakış açıların belirlemesine yönelik bir araştırma. Uluslararası Alanya İşletme Fakültesi Dergisi, 4(1), 17-25.

Çardak, O. (2009). The determination of the knowledge level of science students on energy flow through a word association test. Energy Education Science and Technology, 1(1), 139-155.

Dias Daniel, A., Costa, R.A., Pita, M. and Costa, C. (2017). Tourism Education: What about entrepreneurial skills? Journal of Hospitality and Tourism Management, 30, 65-72.

Ekici, G. ve Kurt, H. (2014). Öğretmen adaylarının aids kavramı konusundaki bilişsel yapıları: Bağımsız kelime ilişkilendirme testi örneği. TSA, 18(3), 267-306.

Giresun Üniversitesi Öğrenci İşleri Dairesi Başkalığı. (2019). 2019 yılı aktif öğrenci sayısı. 8 kasım 2019 tarihinde http://oidb.giresun.edu.tr/tr/page/2019-aktif-ogrenci-sayisi/2777 adresinden erişildi.

Gürbüz, R. ve Güleç, İ. (2016). Türkiye'de eğitim gören yabancı öğrencilerin Türkçeye ilişkin görüşleri: Sakarya üniversitesi örneği. Sakarya University Journal of Education, 6(2), 141153.

Hacıoğlu, N., Kaşl1, M., Şahin, S. ve Tetik, N. (2008). Türkiye'de turizm eğitimi. Ankara: Detay Yayınc1lik.

Iş1klı, H. (2001). Internet Alan isimleri sistemi markalar ve alan isimleri arasındaki ilişki. Ankara: Devlet Planlama Teşkilatı Yayın ve Temsil Dairesi Başkanlığı Yayın ve Basım Şube Müdürlüğü.

Kaya, O.N. (2003). Fen bilimlerinde kavram haritaları. Pamukkale Üniversitesi Eğitim Fakültesi Dergisi, 13(1), 70-79.

Keung ,S.,W. (2000). Tourist's perception of hotel frontline employess' questionable job-related Behaviour. Tourism Management, 21(2), 121-134.

Kılınç, A. (2007). Bir öğretim stratejisi olarak kavram haritalarının kullanımı. Yüzüncü Yıl Üniversitesi Ĕ̈itim Fakültesi Dergisi. 4(11), 21-48.

Kıroğlu, K., Kesten, A. ve Elma, C. (2010). Türkiye'de öğrenim gören yabancı uyruklu lisans öğrencilerinin sosyo-kültürel ve ekonomik sorunları. Mersin Üniversitesi Eğitim Fakültesi Dergisi, 6(2), 26-39.

Kızılırmak, İ. (2000). Yüksekokulların turizm ve otelcilik programlarının turizm sektörünün beklentileri doğrultusunda değerlendirilmesi. Milli Eğitim Dergisi, 147, 54-60.

Misırl1, İ. (2002). Turizm sektöründe meslek standartları ve mesleki belgelendirme sistemi. 
Anatolia Turizm Araştırma Dergisi, 13(1), 39-55.

Polat, G. (2013). Determination of the cognitive structures of year secondary school students through word association test techniques. Necatibey Eğitim Fakültesi Elektronik Fen ve Matematik Eğitimi Dergisi (EFMED), 7(1), 97-120.

Sevimli Deniz, S. ve Çelik, E. (2018). Turizm eğitimi alan öğrencilerin turizm algısının apriori algoritması ile incelenmesi. Sosyal Bilimler Enstitüsü Dergisi, (özel sayı), 207-227.

Şahin, İ. ve Fındık, T. (2008). Türkiye'de mesleki ve teknik eğitim: mevcut durum, sorunlar ve çözüm Önerileri. Türkiye Sosyal Araştırmalar Dergisi, 12(3), 65-86.

Tezcan, M. (1996). Eğitim sosyolojisi. Ankara: Feryal Matbaas1.

Usta, S., Sayın, Y. ve Güzelipek, Y.A. (2017). Yabancı uyruklu öğrencilerin kente ve üniversiteye uyumu: Karaman ili örneği. Yükseköğretim ve Bilim Dergisi, 7(3), 565-567.

Ünlüönen, K. ve Boylu, Y. (2005). Türkiye'de Yükseköğretim düzeyinde turizm eğitimindeki gelişmelerin değerlendirilmesi. Elektronik Sosyal Bilimler Dergisi, 3(12), 11. 